CENTRE FOR THE STUDY OF ECONOMIC AND

SOCIAL CHANGE IN EUROPE (CSESCE)
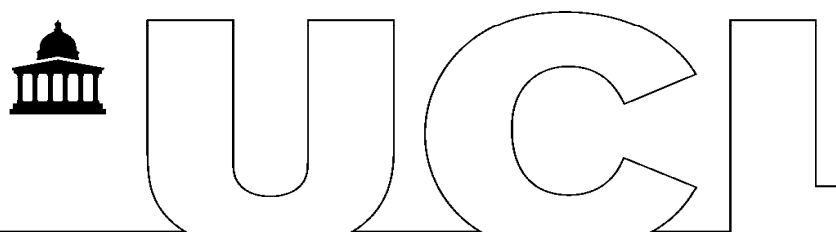

UCL SSEES

Centre for the Study of Economic and Social Change in Europe

\title{
HIERARCHY OF GOVERNANCE INSTITUTIONS AND THE PECKING ORDER OF PRIVATISATION: CENTRAL-EASTERN EUROPE AND CENTRAL ASIA RECONSIDERED
}

\author{
Tomasz M Mickiewicz
}

${ }^{a}$ Corresponding author: t.mickiewicz@ucl.ac.uk

UCL SSEES, 16 Taviton Street, London, W1 0BW, UK.

Economics Working Paper No.90

August 2008, rev. July 2009

Centre for the Study of Economic and Social Change in Europe UCL School of Slavonic and East European Studies

Gower Street, London, WC1E 6BT

Tel: $+44(0) 2076798519$

Fax: $+44(0) 2076798777$

Email: csesce@ssees.ucl.ac.uk 


\title{
Hierarchy of Governance Institutions and the Pecking Order of Privatisation: Central-Eastern Europe and Central Asia reconsidered
}

\author{
Tomasz M. Mickiewicz*
}

\begin{abstract}
We discuss property rights, corporate governance frameworks and privatisation outcomes in the Central Eastern Europe and Central Asia (CEECA) region. We argue that while CEECA still suffers from deficient 'higher order' institutions, this is not attracting sufficient attention of international institutions like EBRD and World Bank, which focus on 'lower order' indicators. We discuss factors that may alleviate the negative impact of the weakness in institutional environment and argue for the pecking order of privatisation, where equivalent privatisation is given a priority, but speed is not compromised.
\end{abstract}

Keywords: property rights, constraints on executive, corporate governance, law, regulation, ownership, privatisation, mass privatisation, Central Europe, Eastern Europe, Russia, Czech Republic, transition

JEL classification: G34, L33, P26

\section{INTRODUCTION}

Eastern-Central Europe and Central Asia (CEECA) share a common past. Twenty years ago, between 1989 and 1992, the Soviet system collapsed producing "a sharp break from established procedures" and institutions (Williamson, 2000, p. 598). Twenty nine independent countries emerged. ${ }^{1}$ Initially characterised by a similar institutional structure (command economy with dominant state property and authoritarian governments), now they represent a wide variety of outcomes and the process of institutional transformation has not been finished yet, at least for

Address for correspondence: Department of Social Science, SSEES, University College London, Gower

Street, London WC1E 6BT, United Kingdom, Tel: 00-44-20-7679 8757; Fax: 00-44-20-7679 8755; E-mail:

t.mickiewicz@,ucl.ac.uk. I am indebted to Stan Mickiewicz for assistance.

1 Following the standard convention established by the European Bank for Reconstruction and Development (see for instance: EBRD, 2007), we include here the former republics of Yugoslavia and Albania, which were communist countries in the past, albeit not the members of the Soviet Block. We also include the former Soviet republics in Central Asia and the Caspian Sea region and Mongolia. 
some of them (Aslund 2007; Havrylyshyn, 2006; Mickiewicz, 2005, and others). External liberalisation and re-integration with the outside world formed an important part of this process. Amongst this group, ten countries joined the European Union between 2004 and 2007, and a few more (in the Balkans) are expected to join within the next several years (at time of writing). However, even for the countries that are either too large to join (especially the Russian Federation) or probably too far away (e.g. Kazakhstan), the European Union remains the gravity centre both for trade (Gros and Steinherr, 2004), and for potential institutional learning.

In this paper we discuss the corporate governance frameworks and post-privatisation outcomes in the CEECA region. We first argue that while corporate governance frameworks differ in those economies (both as compared with other countries, and between each other), the critical issue relates to the quality of 'higher order' institutions, protection of property rights in particular. Next, we explore which factors were associated with better institutional outcomes. We consider both the characteristics of the political regimes that emerged early on and the role of external factors. Subsequently, we discuss privatisation, and argue that the same factors that led to improved corporate governance were also responsible for the differences in privatisation outcomes.

The perspective adopted in this paper is that of institutional economics. The structures of exchange are conditional on institutions. In particular, autonomous market structures function well only where market participants see clear constraints on arbitrary intervention by the government and by other influential economic players so that contractual rights are not abused. 


\section{CORPORATE GOVERNANCE IN CEECA}

\subsection{Fundamentals: strong property rights and freedom from corruption}

Williamson (2000) presents a simple multi-level framework for the institutional economics. The top level relates to slow-changing informal institutions, customs and culture. Next come property rights systems. Subsequent level relates to formal governance and regulatory structures, both voluntary adopted and those backed by the government, including corporate governance. Following that we have individual decisions and strategies of economic agents, which finally shape the economic outcomes.

Similarly, Dyck (2001) places property rights at the beginning of the "governance chains". Weak property rights imply lack of incentives both to reinvest earnings and to the provision of external funding (Dyck, 2001). Moreover, the controlling stakeholders may be inclined not just to abstain from investment, but to actively disinvest by transferring assets and value outside the company, and possibly outside the high-risk country the company is located in (capital flight).

Property rights contain two key elements: (i) freedom from "arbitrary action by political actors" (Dyck 2001, 69) that may lead to a (partial or total) expropriation by the state, and (ii) protection from private expropriation, which imply effective enforcement of stable laws (rule of law), and an effective judiciary system (Levine 2005, 69). Acemoglu and Johnson (2005) argue that the first dimension, closely linked to the constraints on the executive branch of the government, is more fundamental. However, both dimensions are correlated. In particular, the rule of law protects from both private expropriation and state expropriation. On the opposite end of the spectrum, a deficient system of private contracting creates a void, in which power 
structures replace the market. And the private power structures are typically linked with the government: in a dysfunctional environment, where mechanisms of democratic control are weak, individual criminals and corrupt officials develop close ties ${ }^{2}$. Thus, threats from private and public expropriation are related. If they persist, the access to property rights protection becomes uneven (Sonin, 2003) and political capitalism develops.

Poor protection of property rights results in corruption. Poor rule of law creates opportunities both for extortion of benefits by government officials (Tanzi, 1998) and for state capture by private criminals, who use the state structures of power against their market competitors. In addition, the empirical indicators of freedom from corruption overlap directly with the property rights measures in one important aspect: the latter include an assessment of corruption in the judiciary system, the mother of all corruption (Beach and Kane, 2007).

Now we turn to the assessment of the property rights protection and of freedom from corruption in CEECA. Column 1 of Table 1 presents the index of property rights protection compiled by Heritage Foundation / The Wall Street Journal. In column 2 we present their ranking of freedom from corruption, which is based on Transparency International (TI) data supplemented with experts' assessment for few countries where TI scores were not available (Beach and Kane, 2007). These measures represent the indicators of the 'higher order' institutions. In contrast, columns 3-5 focus on narrowly defined measures of contract enforcement as defined by World Bank: estimated average time and financial cost of enforcing a simple financial contract and number of procedures encountered in the process.

2 For illustration how the process works in practice, see for instance: Politkovskaya (2007), esp. Chapter 4, "How to Misappropriate Property with the Connivance of the Government". For more academic treatment, see: Ledeneva (2006), esp. Chapter 7, "Post-Soviet Tolkachi: Alternative Enforcement and the Use of Law". 
After twenty years of institutional transition, the diversity in outcomes is striking. Property rights in Estonia are ranked highest in the whole group of CEECA on par with the UK, US and Germany. In contrast, both Bosnia's and Turkmenistan's scores are the same as for the unreformed Communist Cuba. In general, new EU members (apart from Bulgaria and Romania) score higher than the others. On the other hand, a pattern related to the narrowly defined contract enforcement is less clear. In particular, while Russia has one of the worst scores on the incidence of corruption, its scores on contract enforcement are visibly better, reflecting some improvement in judicial practice in the early 2000s. Yet, effectiveness in delivering decision, speed and low number of judicial procedures is a misleading measure: it tells us little about the likelihood that the system delivers justice. And property rights can be abused outside the courts with the latter not becoming involved. This is why focus on corruption and on fundamental security of property rights may be a more realistic approach, even if the available measurement is less exact. ${ }^{3}$

\{Table 1 about here\}

Our next question is to establish if transition countries differ in their 'higher order' institutions from comparator countries outside the former Soviet block. For this purpose we run few regression models using the world sample of countries. We regress property rights and corruption indices on two dummy variables representing two sub-groups of the transition economies: (i) countries that signed the EU agreements early on (by 1995); these are the same countries that joined the EU by 2008 (denoted CEECE-EU) and (ii) all other transition

3 That may relate to property rights indicators, which are based on experts' assessment. Corruption measures have more direct foundation in empirical research, as they are derived from survey data. 
economies, that is those, which did not participate in the EU integration process or where the process started late (denoted CEECE-non EU). Those tests are intended to establish if there are differences in institutional quality between the transition countries and the world sample. We run those models separately for 1998 and 2008, to see if the results change over time. In each case we also include the logarithm of GDP per capita (purchasing power parity) and the legal origin dummies (with transition countries falling into either German or French category), where English legal origin is taken as benchmark (omitted category). Given that the measures of corruption and property rights have different distributions for 1998 and for 2008, ordered probit is a more approproate estimator for 1998 (models 1 and 2), while 2008 models may be estimated using the ordinary least square regression (models 4 and 5). However, to illustrate that the results are not sensitive to the use of estimator, we additionally run an ordered probit model on 2008 data (model 3), which is a direct equivalent of the OLS estimation in model 4. Results are presented in Table 2 below.

\{Table 2 about here $\}$

What we find is that the CEECA economies that entered the process of EU integration early on have property rights that are not significantly different from the world population (the CEECA-EU coefficients remain insignificant in models 1, 3 and 4). In contrast, in the CEECA countries with no early EU links, the property rights are weaker (CEECA-non EU coefficients are significant in models 1, 2 and 4). Interestingly, in both groups of countries, corruption remains a serious problem, albeit more so in the "non-EU' group (model 5). 
To get a little more insights into between-country differences, figures 1 and 2 below present the level of property right protection and freedom of corruption plotted against the world sample after the impact of GDP per capita is eliminated. ${ }^{4}$ Estonia scores highest on both freedom of corruption and property rights dimension. Belarus, Russia, Kazakhstan, Croatia and Romania score low on both.

$\{$ Figures 1 and 2$\}$

$4 \quad$ Rich countries have better institutions and that should be taken into account when we form expectations about institutional quality. 


\subsection{What Fills the "Institutional Void"}

Where property rights are not well protected and legal provisions of corporate governance are missing or remain inadequate, social organisation falls back on the more fundamental level of informal institutions. If based on accumulated social capital, informal institutions sustained 'from below' may to a large extent substitute for the formal order. Unfortunately, under the Communist system, an autonomous 'social tissue' has been destroyed. The capacity for effective selforganisation in ex-Soviet countries remains low: they are "truly individualistic societies with little capacity for association. In such a society, both families and voluntary associations are weak" (Fukuyama,1995, p. 28) ${ }^{5}$.

Where self-organisation is weak, the informal order is being imposed 'from above' by those with the local power to coerce, that is either by the state administration, organised crime or, most likely both, colluding (Varese, 2005).

While the disorganisation of the old command economy led to a temporary surge in organised crime in the 1990s, the situation in the early 2000s seems to be different. An inspection of World Bank 'Doing Business' survey data reveals that the CEECA do not suffer from the extent of criminal damage, which is characteristic for some Latin American countries. For instance, looking more closely at a few countries with a comparable (middle range) level of GDP

\footnotetext{
5 Empirical evidence for this is provided by World Value Survey, see $<<$ http://www.worldvaluessurvey.org/ $>>$. Social capital is defined by capacity for self-organisation, measured by participation in both voluntary organisations and in elite-challenging actions (see Welzel et al., 2005). Social capital is closely correlated with 'self expression values' as contrasted with "survival values". Amongst the ex-Soviet countries, Russia, Moldova, Ukraine and Romania score lowest and East Germany, Czech Republic, Croatia and Slovenia score highest.
} 
per capita we find that the loss due to theft, robbery, vandalism and arson against the firm expressed as percentage of sales amounted to $5.31 \%$ in Guyana and to $3.85 \%$ in El Salvador, but only to $0.15 \%$ in Romania, $0.31 \%$ in Kazakhstan and $0.52 \%$ in Russia. Similarly, while companies in Peru reported a staggering $12.13 \%$ security cost of sale, the corresponding percentage was only $0.43 \%$ in Romania, $0.61 \%$ in Kazakhstan and $0.77 \%$ in Russia. This implies that even in those CEECA economies, where the political order did not lead to strong 'higher order' institutions (to rule of law and to strong property rights), the social organisation evolved from the situation of "roving banditry" to "stationary banditry" (Olson, 2000), that is some elementary order sustained by local monopolies of power and coercion emerged.

Thus, in the economies of CEECA, where the corporate governance frameworks are inadequate, the substitution comes primary in a form of an arbitrary intervention from the government administration.

\subsection{EBRD Governance Indicators; from State to Market}

Our discussion above leads us to conclude that the linear ordering of corporate governance chain spread between arbitrary government intervention at the initial point and the rule of law at the other end of the spectrum, is a perspective that fits the developments in CEECA well. Indeed, this is an approach implicit in the "governance and restructuring" index published annually by the European Bank for Reconstruction and Development (EBRD, 2007) to measure corporate governance reform in the CEECA region. The low end of the scale (represented by a score of 1) denotes widespread state intervention affecting corporate performance via "lax credit and subsidy policies weakening financial discipline at the enterprise level" coupled with no effective corporate governance law. In this lowest category we find Belarus and Turkmenistan, 
the two countries that departed very little from the old command economy regime (Table 3 , column 1). Soft budget opportunities imply that the managers focus on rent-seeking (on the "control sphere" activities, using Kornai's (1986) terminology).

In contrast, the top end of this scale represents "effective corporate control exercised through domestic financial institutions and markets" (ranked 4.67). As illustrated in Table 3, no CEECA countries achieved this high score yet. The four countries that score the highest are: Estonia, Hungary, Poland and the Slovak Republic (3.67). Czech Republic comes next (3.33). Consistent with the pattern related to property rights discussed above, those are all new EU member states.

\{Table 3 about here\}

\subsection{Self-dealing}

Moving further down the "governance chain" (Dyck 2001) we proceed from the general protection of property rights against expropriation and general assessment of the quality of governance, to the more narrow issue of protection of shareholders both against each other and against the managers (see: La Porta et al. 1997; 1998). Here, the question relates to the protection of property rights as narrowed down to the financial contract between the shareholders and the controlling stakeholders. Djankov et al. (2008) present indicators of protection of minority shareholders against expropriation based on a survey of Lex Mundi legal firms, incorporating both the characteristics of the formal legal provisions and the sanctions related to the enforcement process. However, unlike the broader property rights indicators discussed above, this survey focuses on the formal process instead of the actual practice: accordingly, more precision comes at 
comes at cost of a narrower scope. Aggregate scores are reproduced in Table 4 below. Higher scores imply better legal protection.

$\{$ Table 4 about here $\}$

To verify if CEECA differ from the rest of the world's sample with respect to the level of legal protection, we run the regression models similar to those presented by Djankov et al. (2008) (which include GDP per capita and legal origin indicators as explanatory variables), adding a new dummy denoting the CEECA economies. We could not reject the hypothesis that the CEECA economies are not different from other countries neither by using those models (as documented in column 2 of Table 5) nor by simple t-tests of the differences in means between the CEECA and other economies. However it is difficult to declare if this is because many CEECA economies underwent a process of institutional strengthening of their corporate governance as documented by Pistor (2004), or just because the indicators miss some dysfunctional features of actual practice, consistent with our argument in section 2.1 above. In any case, even as assessed by formal process only, the progress has been uneven. At the time of Djankov et al. (2008) survey, Ukraine offered almost no formal legal protection to minority shareholders, being positioned on the bottom of the world list, jointly with Ecuador (Table 4, column 4).

$\{$ Table 5 about here $\}$ 


\subsection{Corporate governance codes}

Finally, we move to corporate governance codes, which have voluntary nature and may reflect a mixture of actual practice and aspirations, indicating the direction in which the corporate governance practice is evolving. Nevertheless, they do affect the behaviour of companies seeking finance on capital markets, given that the 'comply or explain' principle applies typically. While the provisions may also be extended to non-listed companies, the primary significance of the codes relates to listed firms (Aguilera and Cuervo-Cazurra, 2004; Heugens and Otten, 2007; Zattoni and Cuomo, 2008). Corporate governance codes are introduced by stock exchanges, governments, investors', director's, managers' or professional associations or a conjuncture of those (Aguilera and Cuervo-Cazurra, 2004) and provide uniform frameworks of reference.

Heugens and Ottens (2007) study may be used to provide evidence for the weakness of

formal corporate governance codes in CEECA. They performed content analysis of all corporate governance country codes available in the period up to 2004. Their set of thirty eight countries contains seven CEECA economies, including the three largest: Russia, Poland and the Czech Republic. Based on the principal component analysis of all aspects of governance codes the authors reduced the data to a small number of latent components. The two with highest eigenvalues relate to:

(component 1) the organisational design, defined primarily by the position and the extent of the functions of the board of directors,

(component 2) provisions that endow blockholders and other key stakeholders (esp. employees), with special control rights.

It is interesting to notice, that those two key dimensions are to a large extent consistent with the traditional distinction between the "Anglo-Saxon" and the "German-Japanese" models 
of corporate governance (Franks et al., 1990; Frankel et al., 1991). In particular, the US scores high on the organisational design axis, which reflects strong control functions of the board of directors. In general, the focus on board of directors is typical for the common law countries (Zattoni and Cuomo, 2008) and for the US in particular (Branson, 2008). On the other hand, a stronger position of blockholders is typical for Japan and (to smaller extent) to Germany; both

legal systems are related, as Japan's law has German legal origins (La Porta et al., 2008). When we use Heugens and Otten's (2007) components (as defined above) to position the CEECA economies (see Figure 3 below), the latter come across as offering neither strong control rights to blockholders, nor organisational design that strengthens the auditing, nomination and remuneration functions of the boards.

Arguably, the existence of a corporate governance code is itself an indicator of some progress with corporate governance reform. Thus, even if the seven CEECA economies had those codes and were therefore included in the Heugens and Otten's (2007) study, there are still twenty two that did not have a corporate governance code at all, at time of their study (i.e. until 2004).

\{Figure 3 about here $\}$

\section{FACTORS IN CORPORATE GOVERNANCE REFORM}

We now turn to the discussion of factors that may trigger the process of corporate governance reform. We start with the internal sources of reform (public and private action) and next we discuss external influences. 


\subsection{Local reform: specialised regulation and private action as responses to weak legal environment}

Even where the quality of 'higher order' institutions (no rule of law, inadequate protection of property rights) remains low, it is possible that some semi-autonomous systems of higher quality institutions emerge. In particular, there is a possibility of a relatively strong capital market with a limited group of companies adopting high corporate governance standards (see Köke and Schröder, 2006), even if the average practice of the corporate sector outside the formal capital market remains weak. While good organisation of capital markets is one of the most difficult regulatory challenges (alongside proper anti-monopoly policies and regulation), it has a more 'local' character in a sense of a possibility of creating a subsystem that can function relatively well, even if other elements of the broader institutional business environment fail. It also reflects our earlier discussion on corporate governance codes: these may but not need to extent their provisions onto non-listed companies and may provide pockets of good governance even if the overall business legal framework remains weak (Aguilera and Cuervo-Cazurra, 2004).

However, where autonomous stock exchange regulations substitute for the general protection by corporate law, the former need to be further-reaching and therefore come at a higher cost to participating companies. In turn, if entering the stock market is expensive, most of the companies will stay outside.

This 'two-tier' system, with a large, developed stock market and a deficient business law environment remains characteristic for the Russian Federation, which scores low (2.33) on the corporate governance EBRD indicator (at sample median), but is given a relatively high sixth position on the securities markets indicator, behind the Czech Republic, Estonia, Hungary, 
Lithuania and Poland, but jointly with Bulgaria, Croatia, Latvia, Romania, Slovak Republic and Slovenia (scoring 3) (see above: Table 3, columns 1 and 4).

While a well-functioning subsystem based on specialised regulation may be one response to compensate for a generally deficient legal environment (Glaeser et al., 2001), private actions by firms may be another. Some companies may compensate for general deficiencies in corporate governance regimes by adopting appropriate strategies oriented on signalling: firms that require significant access to external funding may substitute for the inadequate external legal provisions with good individual corporate practice and reputation building. That explains why some of the largest Russian companies may in fact adopt higher quality corporate governance practice than their Central European counterparts (McGee, 2006).

A related phenomenon is the impact of foreign direct investment. Filatotchev et al. (2007a) find that foreign presence on boards is a significant factor affecting performance via enhanced managerial flexibility (see also: Filatotchev et al. (2001) and Wright et al. (2002)). While foreign investors import corporate governance practices to local firms they control, that may create spillover effects and institutional learning. An important mechanism here is that for countries where capital markets function better, for the largest firms there is a continuous process of change in control and firms are moving back and forth between domestic and foreign control (eg.: Bishop et al. 2002). Thus, "external benefits" resulting from the implementation of good corporate governance practices by foreign owners are conditional on well functioning capital markets. 


\subsection{External versus internal factors in corporate governance reform}

In Table 6 we report a simple set of regressions on the cross-section of 28 CEECA countries, where latest values of the EBRD indicators (as presented in Table 3) are regressed on the indicators of EU integration and of constraints on the executive branch of the government, both taken at values ten years before, to alleviate the simultaneity bias. The results reveal a strong association between all the individual EBRD reform indicators and either the EU affiliation or the fundamental characteristics of the political system. Interestingly, the 'corporate governance and restructuring' indicator correlates little with the EU affiliation, once we control for political institutions: the impact of the latter dominates.

General pattern of the influence of the EU integration and of political reforms on economic reforms is not surprising. Empirical tests provided by Di Tommaso et all. (2007) suggest that the effect of the EU accession process on reforms is very strong, even if some additional reverse, feedback effects are also possible (see also Havrylyshyn, 2006; Gros and Steinherr, 2004). Also, the impact of political reforms on economic reforms is well established in empirical studies (see: Falcetti et al., 2002; Mickiewicz, 2005). What is more interesting here, is to see that the strongest link is the one between the corporate governance systems and basic characteristics of the political system. As argued by Acemoglu and Johnson (2005), constraints imposed on the executive branch of the government are inherently associated with protection of property rights. And, as argued above, the property rights form an indispensable basis for sound corporate governance regimes.

\{Table 6 about here\} 


\section{OUTCOMES: PRIVATISATION, OWNERSHIP STRUCTURE, PERFORMANCE}

We now move from the evolution of corporate governance legal frameworks to corporate outcomes. We will discuss the ownership structures and performance. In this context we will also explore the privatisation strategies.

\subsection{Ownership structures and privatisation}

Table 7 provides some basic statistics on ownership structures derived from the Business Environment and Enterprise Performance Survey (BEEPS) conducted by the EBRD in the CEECA economies in April and May 2005. These statistics should be viewed with some caution, as they may be affected by the sampling frames (Synovate, 2005), yet this is still the most reliable information we have. The country averages we derived from the BEEPS data exclude small firms (only the companies with 50 employees are retained). Column 1 of Table 7 presents the average self-reported percentage held by the largest shareholder(s).

Column 2 relates to the self-reported number of largest shareholders (blockholders). Here we report the percentage of companies that have more than one major shareholder. Bennedsen and Wolfenzon (2000) suggest that a group of large shareholders may be associated with better performance outcomes, in contrast with the presence of one dominant owner. Consistent with this, available empirical results indicate that firms with concentrated ownership, but with more than one strong blockholder perform best (Kirchmaier and Grant, 2005; Aluchna, 2006), which makes this characteristic an important one to look at. In particular, efficient corporate control structures emerge where strategic shareholders without legal (50\%) control are counterbalanced 
by strong minority blockholders, investment and pension funds in particular (see also Filatotchev et al. 2007b).

$77 \%$ of medium and large size companies included in the 2005 BEEPS sample have just one dominant owner. It indicates that by the early 2000 s, the ownership structures remained highly concentrated and the extent of dispersed ownership in CEECA has been negligible. The variable that correlates most with the more diversified ownership (as measured by the presence of additional blockholders) is simply the extent of privative sector (share of private sector in GDP; correlation coefficient: 0.37 ). In turn, the extent of private sector is closely related to the EBRD indicator of large scale privatisation (the correlation coefficient for the extent of private sector and the EBRD privatisation indicator is very high, at 0.90 ). And we know from Table 5 above, that the key drivers of the privatisation process were the EU integration programme and political democratic reforms.

One may notice however that Russia scores particularly well on the presence of additional blockholders, with over one third of companies having more than one blockholder (Table 7, column 2). Here, ownership structures and resulting internal governance features may (partly) compensate for the weakness of the general governance frameworks, inducing some positive performance effects.

$\{$ Table 7$\}$

\subsection{Performance, privatisation, corporate governance and corporate control structures}

Figure 4 presents two key privatisation parameters: the approximate share of the private sector in GDP (on the horizontal axis) and the amount of cumulative privatisation revenues (on 
the vertical axis). With some simplification, the first may be interpreted as a proxy for the extent of privatisation ${ }^{6}$. The second dimension (the volume of privatisation revenues) may be taken as an indicator of the quality of privatisation programmes: high privatisation revenues imply that the ownership titles has been transferred to the owners, who paid prices corresponding more closely to the value of assets, and therefore may be expected to make a better use of those assets. Described this way, the 'equivalent' privatisation is distinguished from the "non-equivalent" privatisation, where shares were transferred for free or below market value either to the general public or to insiders. "Equivalent" privatisation is associated with extensive participation of outside investors (foreign investors in particular), and the latter lead to sound firm level governance structures and better performance (Megginson and Netter, 2001; Djankov and Murrell, 2002; Brown et al., 2007; D’Souza et al., 2007; Iwasaki, 2007 for Russia; in comparison, Boubakri et al., 2007 found that the effect of foreign ownership is less pronounced for nontransition economies).

To account for the fact that privatisation revenues are correlated with the extent of privatisation, we are interested in countries that are positioned above the linear fit between these two variables. In particular, we find Hungary well above the upper-end section of the OLS line: not only the extent of privatisation was amongst the widest in Hungary, but also privatisation revenues were high thanks to the focus on privatisation methods oriented on direct sales to outside owners, with a key role of foreign direct investment. More surprising is the position of the Slovak Republic, very close to Hungary, and the Czech Republic, slightly below Hungary yet still amongst the group of countries with high privatisation revenues: the Czech Republic (and to

$6 \quad$ The share of the private sector in GDP is affected primarily by the extent of privatisation, but also by the rate of (successful) entry of new firms and by the extent of downsizing of the residual state sector. 
smaller extent, the Slovak Republic) went through the extensive 'non-equivalent' mass privatisation programme, which produced no revenue beyond a small fee collected from the participating public to cover administrative costs. However, a significant number of enterprises in which outside investors expressed an interest was excluded from the mass privatisation programme and sold directly (Coffee, 1996). In addition, the Czech mass privatisation programme was complemented in the second half of the 1990s by an extensive wave of direct privatisations to outside investors, including foreign ones. In contrast, in Poland, while many enterprises were indeed privatised via direct sales to outside investors (as asserted by Spicer et al, 2000), the extensive role was also played by employee buy-outs based on an underpriced transfer of assets (Bałtowski and Mickiewicz, 2000; Andreff, 2006). This explains a relatively lower level of privatisation revenues in Poland. However, the most characteristic example of non-equivalent privatisation is the Russian Federation, where the shares of industrial enterprises were transferred to insiders and to the general public (Blasi et al., 1997; Gustafson, 1999). Moreover, while Russia has an extensive natural resources sector that could potentially produce high privatisation revenues, the dominant role in the privatisation of those was played by the 'debt for equity' scheme, where underpriced transfers created the group of powerful domestic 'oligarchs'. Here, Russia may be contrasted with neighbouring Kazakhstan, where early higher participation of foreign investors in the oil sector privatisation produced higher government revenues. However, non-equivalent privatisations were characteristics not only for the CIS countries. On Figure 4, we find Slovenia located very close to Russia due to its reliance on the employee privatisation scheme.

\{Figure 4 about here\} 


\subsection{Mass (voucher) privatisation}

The mass privatisation programme was an original response to the dilemma faced by the policy-makers during the process of transition from the command to the market economy. In contrast, traditional privatisation methods used elsewhere (in non-transition economies) were based on property transfers either via direct sales of controlling shares to a strategic investor or via sales to blockholders coupled with flotation on the stock exchange (Megginson and Netter, 2001). Similarly, flotation via the stock exchange was the preliminary policy choice in the countries that initiated the transition programme that is in Poland and Hungary, yet proved technically difficult and time consuming. It became obvious that it could not be implemented quickly enough to solve the unprecedented problem of privatising whole industries (Mickiewicz, 2005). Besides, accelerating direct sales to outsiders implied deflated prices and was associated with political problems, as large transfers of underpriced assets to politically-connected owners affected the distribution of wealth and could undermine the legitimacy of the reform process. Thus, there was a limit to how much 'equivalent' the privatisation could become, and that limit was determined by demand for assets. Moreover, the outsiders who had sufficient cash resources to participate were either foreign investors or individuals who derived their wealth from their links with the old communist regime. Endowing either of these two groups with underpriced industrial assets was not a politically attractive option. Hungary, where demand from foreign investors was strong enough to guarantee relatively higher prices was an exception rather than a rule.

This situation left the policy makers implementing the privatisation programmes with an alternative either to slow down the programme considerably or to supplement direct sales to outsiders and capital market flotations with 'non-equivalent' privatisation transfers either to 
insiders, to the general public or to a combination of both. Significant transfers to insiders were characteristic for the countries where the position of workers and/or managers was strong, either thanks to the prior existence of independent trade unions (as in Poland; also Bulgaria) or thanks to the heritage of the self-government system (as in Slovenia, or in the Russian Federation where self-government resulted from the partial reforms of the communist system introduced by Mikhail Gorbachev in the late 1980s). In contrast, Czechoslovakia, which had an unreformed centralised economic system, implemented the first mass (voucher) privatisation programme with relatively less concern for the interests of insiders. However, when the mass privatisation programmes were copied later on in various alternative versions in all transition countries except Hungary, far more concessions were typically given to insiders (Coffee, 1996; Estrin and Stone, 1996; Takla, 1999; Mejstrik, 2003; Zemplinerova and Machacek, 2003).

The Czech and Slovak programme was implemented relatively efficiently, with a simple auction mechanism that generated share prices reflecting the companies' values and ensured the equilibrium between the demand (privatisation vouchers) and supply (the shares of privatised companies) (Filer and Hanousek, 2001). However, after the initial wave of enthusiasm (e.g. Coffee, 1996), the programme was met with strong criticism, due to apparent weak governance structures (Spicer et al., 2000; Filatotchev et al., 2003). Yet, after several more years of experience, the assessment has been again rebalanced. As already discussed, mass privatisation was never a single privatisation programme, and in the Czech Republic it was complemented with the efficient small-scale privatisation, new entry (Frydman et al., 1993), and direct privatisations. In addition, conditional on the quality of institutional environment, the weak governance structures produced by mass privatisation evolved towards more efficient ones (Andreff, 2006). As already discussed, there were marked differences in the quality of the 
corporate governance legal frameworks (see Table 1). Relatively more efficient legal

frameworks facilitated significant secondary ownership transfers to outside owners, which in turn improved the internal governance structures.

Third, as already argued, mass privatisation should not be compared with some ideal standard but with feasible alternative programmes as implemented elsewhere. Most recent evidence indicates that the rapid privatisation methods, in particular the mass privatisation programmes, were associated with good macro performance, contrary to earlier criticism (Bennett et al., 2007) ${ }^{7}$. The underlying reason may be that mass privatisation severed the links between the companies and the state early on, which was a critical factor cutting flows of state funds to failing firms and triggering restructuring (Hellman and Schankerman, 2000; Estrin, 2002). In addition, mass privatisation initiated the subsequent evolution in ownership structures.

\subsection{Political economy of privatisation and corporate governance}

The new results obtained by Bennett et al. (2007) just discussed may be contrasted with an earlier view in the transition literature that gradual privatisation could bring better results

$7 \quad$ Gouret (2007) questions Benett et al.'s (2007) results, and presents estimations where mass privatisation does not produce positive macroeconomic effects. However, the problem with the Gouret's (2007) approach is that he introduces dummies for the privatisation methods indicators that switch values more than once over time. In particular, for a number of countries where mass privatisation was introduced early on, his mass privatisation dummy returns to zero between 1995 and 2001. As the general pattern was that the economic growth reemerged in the late phase of transition, this creates a bias against the mass privatisation method. It is difficult to argue that the impact of a mass privatisation programme vanished as soon as the process was completed, as has been implicitly implied by Gouret's (2007) classification. 
(Spicer et al., 2000). According to the latter, possible efficiency loss resulting from leaving some companies under state ownership for longer may be counterbalanced later on by high efficiency resulting from slower privatisation methods oriented on outsider control. Parallel to this, there is indeed some evidence that pre-privatisation restructuring affects post-privatisation performance positively (D'Souza et al, 2007). Similarly, corporate governance reform within the state sector ('commercialisation' or 'corporatisation') preceding privatisation could bring some positive results (Megginson and Netter, 2001 and Djankov and Murrell, 2002). Yet, consistent with survey-based evidence, positive changes in state companies' managerial strategies were in fact triggered by expectations of subsequent privatisation (Pinto et al., 1993; see also discussion in Mickiewicz, 2005), therefore timing of the latter remains a critical issue.

The key argument for fast privatisation methods is that the residual state sector could become easily entrenched. Bałtowski and Mickiewicz (2006) document the process of deterioration in corporate governance legal regulations triggered by the growing political importance of the residual state sector. In particular, the state companies had became an attractive target for political extraction of private benefits (including politically-motivated board appointments) and that created disincentives for corporate governance reforms.

Empirical cross-country evidence on the corporate political economy of CEECA is provided by Hellman et al. (2003). The authors distinguish between 'influence' over the state legal framework that does not involve direct corruption, and 'state capture', where law is bought and legislators and administrators are outright bribed. They find that state firms are far more likely to influence the government to distort legislation and legal practice in their favour. This is consistent with negative correlation between the EBRD corporate governance and restructuring 
indicator and the share of the state sector in GDP. ${ }^{8}$ However, the second mechanism they investigate is 'state capture', where favours and distortions in law are bought via corrupting government representatives. State firms, relying on more direct links with the state administration are unlikely to resort to it. The phenomenon is most characteristic for the partly privatised, partly reformed economies, where new private firms have incentives to bribe officials to match the state sector influence. Moreover, the corrupt behaviour is far more typical for larger firms and for environments where property rights are weakly protected. In addition, there is no evidence that foreign companies behave differently from domestic players in such an environment (Hellman et al. 2002). The danger is that partial reforms evolve into political capitalism where big players ('early winners') consolidate their initial post-privatisation gains at the cost of damaging both minority interests of shareholders created via privatisation, competitive capital markets and competitive product markets by mounting entry barriers (Hellman, 1998; Hellman et al., 2003; Slinko et al., 2005; Havrylyshyn, 2006). Universal property rights are replaced by 'individualised protection' (Hellman et al. 2003) and 'inequality of influence' becomes institutionally embedded (Glaeser et al., 2003; Sonin, 2003) leading to economic inequality (Buccellato and Mickiewicz, 2009).

The results obtained by Hellman et al. (2003) have far reaching implications.

First, they make earlier results on the link between corporate control structures and performance look problematic. Hellman et al. (2003) established that state capture results in better financial performance even if this performance is more of a short-term nature, given their findings on underinvestment in companies involved in rent-seeking activities. This may explain

$8 \quad$ Taking 2008 share of GDP and corporate governance EBRD indicator, the correlation coefficient is 0.73 (significant at 0.001). 
why in the results of individual studies summarised by Djankov and Murrell (2002) the differences in (short-term) performance indicators resulting from privatisation are less clear-cut for countries with dysfunctional legal frameworks. The explanation is that the impact of real restructuring effects may be counter-balanced by 'control sphere' activities that the typical studies on performance fail to capture.

Second, we may reassess again the case of the mass (voucher) privatisation programme. It is clear from the Hellman et al.' (2003) results that the speed of privatisation matters as it works against entrenchment of the residual state sector, which may be associated with blocking institutional reforms and poor corporate governance (see also Bałtowski and Mickiewicz, 2006). On the other hand, underpriced transfers of assets (especially those generating strong economic rents) to selected players ('oligarchs') endow them with resources which may in turn be used for state capture. The classic example of such a policy relates to the 'debt for equity' scheme in Russia. That contrasts with mass (voucher) privatisations schemes that avoid such feedback effects.

\section{CONCLUSIONS}

Property rights are at the origin of the "corporate governance chain" (Dyck, 2001) and analysing lower order legal regulations alone may be misleading. For example formal indicators of anti-self dealing regulations do not describe the reality of the transition countries well, as they ignore the more fundamental context of poor judicial practice and arbitrariness of state administration. Similarly both World Bank and EBRD reform indicators are better understood only if the fundamental characteristics of the institutional environment are taken into account. 
And it is with respect to property rights and to the related dimension of freedom from corruption that the transition economies still look significantly different from the world comparator countries.

However, while general institutional fundamentals are relatively weak, several factors alleviate the problems.

First, some legal subsystems (formal capital markets in particular) may rely on specialised autonomous regulary regimes creating important pockets of better governance and attracting finance. In the context of stock exchange, the weakness of private enforcement via the judicial system may be counterbalanced by a creation of a strong regulator with sufficient coercion attributes (Glaeser et al. 2001). However, that creates entry cost and limits the size of the stock market; too much corporate governance regulation is costly for firms (Bruno and Claessens, 2007).

Second, domestic firms seeking external finance (foreign in particular) may voluntary adopt strong external audit and transparent, outsider-friendly corporate governance practices, building their reputation vis-a-vis the providers of finance.

Third, some good practices may be imported by foreign companies, having positive spillover effects in corporate governance, however emprical evidence of this is not clear-cut (Hellman et al. 2002).

Fourth, in some of those countries, the presence of more than one strong blockholder may create ownership structures where an equilibrium of private interests leads to better performance.

Fifth, external influence from the European Union has positive effects on the quality of law and legal practice. However, the estimations on determinants of lower order reforms (as captured by EBRD mesures) we present indicate that the impact of higher order institutional 
fundamentals dominate over the impact of the EU integration process (Table 6 above). Countries that were able to adopt political institutions imposing credible constraints on the arbitrary power of the executive branch of the government early on were also successful in building lower order institutions and regulations.

This suggests that conceptual and empirical ordering of corporate governance should be spread between the state of arbitrary intervention by those within the political power structures and the rule of law protecting contract against both government and private infringement. At the initial point, the CEECA economies started from the arbitrary state, yet evolved into different directions. At present, diversity in corporate governance frameworks and control structures within the CEECA group dominates over differences between CEECA and other countries.

While we highlight the quality of "higher order" institutions as a key factor, the internal dynamics of the privatisation process is at least as important. We argue that rapid privatisation transformed anti-reform constituencies into the pro-reform ones, but only provided that it did not lead to highly concentrated oligarchic gains. Ill-designed, rapid transfer of rent-generating assets could create powerful private players interested in protecting their interests at the cost of potential competition. Resulting structures of political capitalism could be at least as dangerous in their political influence on the reform process as a large residual state sector (Hellman and Schankerman, 2000).

If we additionally notice that 'equivalent privatisation' was difficult to implement quickly, we are left with the conclusion that the fast (mass, voucher) privatisation programmes, which avoided the creation of powerful corporate 'oligarchic' structures were feasible second best strategies, even if discounting for their negative side effects (on stock markets in particular). Most recent evidence on the link between mass privatisation and performance (Bennett et al. 
2007) supports this conclusion. In general, we argue that the optimum design of the privatisation strategy may be to adopt a 'pecking order' where the assets met with sufficient demand are privatised with a view to maximise revenue, and next the remaining assets are privatised using fast privatisation strategy. This perspective implies that the standard classification of countries by dominant privatisation methods may be too simplistic: Czech Republic is a good example of a country, which liberalised private entry, and used equivalent privatisation where feasible, but relied on mass privatisation for the rest of its industrial assets. Post-privatisation transfers generating more efficient ownership patterns regardless of the initial privatisation method are equally important. These transfers are again conditional on the quality of the property rights. Outside ownership and motivation of outside owners to invest instead of divesting the assets emerge only where the property rights are credible.

\section{REFERENCES}

Acemoglu, D. and Johnson, S. 2005. Unbundling Institutions. Journal of Political Economy, 113, 949-995.

Aguilera, R. and Cuervo-Cazurra, A. 2004. Codes of Good Governance Worldwide: What is the Trigger?, Organisational Studies, 25, 415-443.

Aluchna, M. 2006. Ownership Concentration and Corporate Performance: Evidence from Poland. In: T. Mickiewicz, ed. Corporate Governance and Finance in Poland and Russia. Houndmills: Palgrave Macmillan, 194-214.

Aslund, A. 2007. How Capitalism Was Built: The Transformation of Central and Eastern Europe, Russia, and Central Asia. Cambridge: Cambridge University Press. 
Andreff, W. 2006. Corporate Governance Structures in Post Socialist Economies: Towards a Central European Model of Corporate Control? In: T. Mickiewicz, ed. Corporate Governance and Finance in Poland and Russia. Houndmills: Palgrave Macmillan, 23-48.

Bałtowski, M., Mickiewicz, T. 2000. Privatisation in Poland, Ten Years After, Post Communist Economies, 12, 425-443.

Bałtowski, M., Mickiewicz, T. 2006. Politicians or Administrators? State Corporate Governance in Poland. In: T. Mickiewicz, ed. Corporate Governance and Finance in Poland and Russia. Houndmills: Palgrave Macmillan, 72-88.

Beach, W. and T. Kane. 2007. Methodology: Measuring the 10 Economic Freedoms. Washington: The Heritage Foundation

Bennedsen, M., Wolfenzon, D. 2000. The Balance of Power in Closely Held Corporations, Journal of Financial Economics, 58, 113-139.

Bennett, J., Estrin, S., Urga, G. 2007. Methods of Privatization and Economic Growth in Transition Economies, Economics of Transition, 15, 661-83.

Bishop,K., Filatotchev,I., Mickiewicz,T. 2002. Endogenous Ownership Structure: Factors Affecting the Post-Privatisation Equity in Largest Hungarian Firms, Acta Oeconomica 52, 443-471.

Blasi, J., Kroumova, M., Kruse, D. 1997. Kremlin Capitalism. Privatising the Russian Economy. Ithaca: Cornell UP.

Boubakri, N., Cosset, J., Guedhami, O. 2005. Postprivatization Corporate Governance: The Role of Ownership Structure and Investor Protection, Journal of Financial Economics, 76, 369-399. 
Branson, D. 2008. The Very Uncertain Prospect of 'Global' Convergence in Corporate Governance, University of Pittsburgh, mimeo.

Brown, D., Earle, J., Telegdy, A. 2007. The Productivity Effects of Privatisation: Longitudinal Estimates from Hungary, Romania, Russia and Ukraine, Journal of Political Economy, 114, 61-99.

Bruno, V. and Claessens, S. 2007. Corporate Governance and Regulation: Can There be Too Much of a Good Thing?, CEPR Discussion Paper, No 6108.

Buccellato, T. and Mickiewicz, T. 2009. Oil and Gas: A Blessing for the Few. Hydrocarbons and Inequality within Regions in Russia, Europe-Asia Studies, 61, 385-407.

Coffee, J. 1996. Institutional Investors in Transitional Economies. In: R. Frydman, Ch. W. Gray and A. Rapaczynski, eds. Corporate Governance in Central Europe and Russia. Budapest: Central European University Press, Vol.1, 111-186.

Di Tommaso, M., Raiser, M. and Weeks, M. 2007. Home Grown or Imported?, Economic Journal, 117, 852-881.

Djankov, S. and Murrell, P. 2002. Enterprise Restructuring in Transition: A Quantitative Survey, Journal of Economic Literature, 40, 739-92.

Djankov, S. 2008. The Law and Economics of Self-Dealing, Journal of Financial Economics, 88, $430-465$.

D’Souza, J., Megginson, W., Nash, R. 2007. The Effects of Changes in Corporate Governance and Restructuring on Operating Performance: Evidence from Privatizations, Global Finance Journal, 18, 157-184.

Dyck, A. 2001. Privatization and Corporate Governance: Principles, Evidence , and Future Challenges, World Bank Research Observer, 16, 59-84. 
EBRD. 2007. Transition Report. London: European Bank for Reconstruction and Development.

Estrin, S. and Stone, R. 1996. A Taxonomy of Mass Privatisation, Transition, 7 (11-12), 8-9.

Estrin, S. 2002. Competition and Corporate Governance in Transition, Journal of Economic Perspectives, 16, 101-124.

Falcetti, E., Raiser, M. and Sanfey, P. 2002. Defying the Odds: Initial Conditions, Reforms, and Growth in the First Decade of Transition', Journal of Comparative Economics, 30, 22950.

Filatotchev, I., Dyomina, N., Wright, M. and Buck, T. 2001. Effects of Post-Privatization Governance and Strategies on Export Intensities in the Former Soviet Union, Journal of International Business Studies, 32, 853-71.

Filatotchev, I., Wright, M., Uhlenbruck, K., Tihanyi, L. and Hoskinsson, R. 2003. Governance, Organisation Capabilities, and Restructuring in Transition Economies, Journal of World Business, 38, 331-347.

Filatotchev, I., Isachenkova, N. and Mickiewicz, T. 2007a. Corporate Governance, Managers' Independence, Exporting, and Performance of Firms in Transition Economies, Emerging Markets Finance and Trade, 43, 65-80.

Filatotchev, I., Isachenkova, N. and Mickiewicz, T. 2007b. Ownership Structure and Investment Finance in Transition Economies, Economics of Transition, 15, 433-460.

Filer, R. and Hanousek, J. 2001. Informal Content of Price Set Using Excess Demand. The Natural Experiment of Czech Voucher Privatisation, European Economic Review, 45, $1619-1646$

Frankel, A., Montgomery, J., Friedman, B. and Gertler, M. 1991. Financial Structure: An International Perspective, Brookings Papers on Economic Activity, 8 (1), 257-310. 
Franks, J., Mayer, C., Hardie J. and Malinvaud, E. 1990. Capital Markets and Corporate Control: A Study of France, Germany and the UK, Economic Policy, 5 (10), 191-216.

Fukuyama, F. (1995) Trust. The Social Virtues and the Creation of Prosperity (New York: Free Press).

Frydman, R., Rapaczynski, R., Earle, J. (eds.). 1993, The Privatisation Process in Central Europe. Budapest: CEU Press.

Glaeser, E., Johnson, S. and Shleifer, A. 2001. Coase versus Coasians, The Quarterly Journal of Economics, 116, 853-99.

Glaeser, E., Scheinkman, J., Shleifer, A. 2003. The Injustice of Inequality, Journal of Monetary Economics, 50, 199-222.

Gouret, F. 2007. Privatisation and Output Behaviour During the Transition: Methods Matter!, Journal of Comparative Economics, 35, 3-34.

Gros, D. and Steinherr, A. 2004. Economic Transition in Central and Eastern Europe. Cambridge: Cambridge University Press.

Gustafson, T. 1999. Capitalism Russian Style. Cambridge: Cambridge University Press.

Helpman, E. 2006. Trade, FDI and Organization of Firms, Journal of Economic Literature, 44, 589-630.

Hellman, J. and Schankerman, M. 2000. Intervention, Corruption and Capture. The Nexus Between Enterprises and the State, Economics of Transition, 8, 545-576.

Hellman, J., Jones, G. and Kaufmann, D. 2002. Far from Home: Do Transnationals Import Better Governance in the Transition Economies?, Working Paper. Washington D.C : World Bank. 
Hellman, J., Jones, G. and Kaufmann, D. 2003. Seize the State, Seize the Day: State Capture and Influence in Transition Economies, Journal of Comparative Economics, 31, 751-773.

Glaeser, E., Johnson, S. and Shleifer, A. 2001. Coase versus the Coasians, Quarterly Journal of Economics, 116, 853-899.

Havrylyshyn, O. 2006. Divergent Paths in Post-Communist Transformation. Houndmills: Palgrave Macmillan.

Hellman, J. 1998. Winners Take All: The Politics of Partial Reform in Postcommunist Transitions, World Politics, 50, 203-234.

Hellman, J., Jones, G. and Kaufmann, D. 2003. Seize the State, Seize the Day: State Capture and Influence in Transition Economies, Journal of Comparative Economics, 31, 751-773.

Heugens, P. and Otten, J. 2007. Beyond the Dichotomous Worlds Hypothesis: Towards a Plurality of Corporate Governance Logics, Corporate Governance: An International Review, 15, 1288-1300.

Iwasaki, I. 2007. Enterprise Reform and Corporate Governance in Russia: A Quantitative Survey, Journal of Economic Surveys, 21, 849-902.

Kirchmaier, T. and Grant, J. 2005. Corporate Ownership Structure and Performance in Europe, European Management Review, 2, 231-245.

Köke, J. and Schröder, M. 2006. The Contribution of CEE Capital Markets to Corporate Finance. In: T. Mickiewicz, ed. Corporate Governance and Finance in Poland and Russia. Houndmills: Palgrave Macmillan, 243-258.

Kornai, J. 1986. Contradictions and Dilemmas: Studies on the Socialist Economy and Society. Cambridge, MA: MIT Press. 
La Porta, R., Lopez-de-Silanes, F., Shleifer, A. and Vishny R. 1997. Legal Determinants of External Finance, Journal of Finance, 52, 1131-1150.

La Porta, R., Lopez-de-Silanes, F., Shleifer, A. and Vishny R. 1998. Law and Finance, Journal of Political Economy, 106, 1113-1155.

La Porta, R., Lopez-de-Silanes, F. and Shleifer, A. 2008. The Economic Consequences of Legal Origins, Journal of Economic Literature, 46, 285-332.

Ledeneva, A. 2006. How Russia Really Works. The Informal Practices That Shaped Post-Soviet Politics and Business (Ithaca and London: Cornell University Press).

Levine, R. 2005. Law, Endowments and Property Rights. Journal of Economic Perspectives, 19, 61-88.

Marshall, M. and Jaggers, K. 2007. Polity IV Project: Dataset Users’ Manual, George Mason University and Center for Systemic Peace, Fairfax, VA.

McGee, R. 2006. Transparency and Disclosure in Russia. In: T. Mickiewicz T., ed. Corporate Governance and Finance in Poland and Russia. Houndmills: Palgrave Macmillan, 25977.

Megginson, W., Netter, J. 2001. From State to Market: A Survey of Empirical Studies on Privatisation, Journal of Economic Literature, 39, 321-389.

Mejstrik, M. 2003. Privatisation and Corporate Governance in the Czech Republic. In: D. Parker and D. Saal, eds., International Handbook on Privatisation. Cheltenham: Edward Elgar, $372-401$.

Mickiewicz, T. 2005. Economic Transition in Central Europe and the Commonwealth of Independent States. Houndmills: Palgrave Macmillan.

Olson, M. 2000. Power and Prosperity (New York: Basic Books). 
Pinto, B., Belka, M. and Krajewski, S. 1993. Transforming State Enterprises in Poland: Evidence on Adjustment by Manufacturing Firms, Brookings Papers on Economic Activity, 1, 213270.

Pistor, K. 2004. Patterns of Legal Change: Shareholder and Creditor Rights in Transition Economies, European Business Organisation Law Review, 1, 59-110.

Politkovskaya, A. 2007. Putin's Russia. Life in a Failing Democracy. New York: Holt.

Slinko, I., Yakovlev, E., Zhuravskaya, E. 2005. Law for Sale: Evidence from Russia, American Law and Economics Review, 7, 284-318.

Sonin, K. 2003. Why the Rich May Favor Poor Protection of Property Rights, Journal of Comparative Economics, 31, 715-731.

Spicer, A., McDermott, G., Kogut, B. 2000. Entrepreneurship and Privatisation in Central Europe: The Tenuous Balance between Destruction and Creation, Academy of Management Review, 25, 630-649.

Synovate. 2005. The Business Environment and Enterprise Performance Survey (BEEPS) 2005: A Brief Report on Observations, Experiences and Methodology from the Survey. Nicosia: Synovate.

Takla, L. 1999. Privatisation in the Czech Republic. In: P. Hare, J. Batt and S. Estrin (eds.) Reconstituting the Market. Amsterdam: Harwood, 135-154.

Tanzi, V. 1998. Corruption Around the World: Causes, Consequences, Scope and Cures, Staff Papers - International Monetary Fund, 45, 559-594.

Varese, F. 2005. The Russian Mafia: Private Protection in a New Market Economy. Oxford: Oxford University Press. 
Welzel, C., Inglehart, R. and Deutch, F. 2005. "Social Capital, Voluntary Associations and Collective Action: Which Aspects of Social Capital Have the Greatest 'Civic' Payoff?”, Journal of Civil Society, 2, 121-146.

Williamson, O. 2000. The New Institutional Economics: Taking Stock, Looking Ahead, Journal of Economic Literature, 38, 595-613.

Wright, M., Filatotchev, I., Buck, T. and Bishop, K. 2002. Foreign Partners in the Former Soviet Union, Journal of World Business, 37, 165-79.

Zattoni, A. and F. Cuomo. 2008. Why Adopt Codes of Good Governance? A Comparison of Institutional and Efficiency Perspectives, Corporate Governance: An International Review, 16, 1-15.

Zemplinerova, A., and Machacek, M. 2003. Privatisation in the Czech Republic: Strengths and Weaknesses. In: Y. Kaluzhnova and W. Andreff, eds. Privatisation and Structural Change in Transition Economies. Basingstoke: Palgrave Macmillan, 202-24. 
Table 1. Property Rights in Central Eastern Europe and Central Asia

\begin{tabular}{|c|c|c|c|c|c|}
\hline Country & $\begin{array}{l}\text { [1] Property } \\
\text { Rights Index: } \\
\text { Heritage } \\
\text { Foundation / } \\
\text { Wall Street J. }\end{array}$ & $\begin{array}{l}\text { [2] Freedom } \\
\text { from } \\
\text { corruption: } \\
\text { Heritage/ } \\
\text { Wall St. J. }\end{array}$ & $\begin{array}{l}{[3] \text { No of }} \\
\text { procedures to } \\
\text { enforce } \\
\text { contracts: } \\
\text { World Bank }\end{array}$ & $\begin{array}{l}\text { [4] Time } \\
\text { (days) to } \\
\text { enforce } \\
\text { contract: } \\
\text { World Bank }\end{array}$ & $\begin{array}{l}{[5] \text { Cost }} \\
\text { (\% of } \\
\text { debt): } \\
\text { World } \\
\text { Bank }\end{array}$ \\
\hline ALBANIA & 30 & 26 & 39 & 390 & 31.8 \\
\hline ARMENIA & 35 & 29 & 50 & 285 & 19.0 \\
\hline AZERBAIJAN & 30 & 24 & 39 & 267 & 18.5 \\
\hline BELARUS & 20 & 21 & 28 & 225 & 23.4 \\
\hline BOSNIA & 10 & 29 & 38 & 595 & 38.4 \\
\hline BULGARIA & 30 & 40 & 40 & 564 & 22.2 \\
\hline CROATIA & 30 & 34 & 38 & 561 & 13.8 \\
\hline CZECH REPUBLIC & 70 & 48 & 27 & 820 & 33.0 \\
\hline ESTONIA & 90 & 67 & 36 & 425 & 17.3 \\
\hline FYR MACEDONIA & 30 & 27 & 39 & 385 & 33.1 \\
\hline GEORGIA & 35 & 28 & 36 & 285 & 29.9 \\
\hline HUNGARY & 70 & 52 & 33 & 335 & 13.0 \\
\hline KAZAKHSTAN & 30 & 26 & 38 & 230 & 22.0 \\
\hline KYRGYZ REPUBLIC & 30 & 22 & 39 & 177 & 22.0 \\
\hline LATVIA & 55 & 47 & 27 & 279 & 12.9 \\
\hline LITHUANIA & 50 & 48 & 30 & 210 & 23.6 \\
\hline MOLDOVA & 50 & 32 & 31 & 365 & 16.6 \\
\hline MONGOLIA & 30 & 28 & 32 & 314 & 26.1 \\
\hline MONTENEGRO & & & 49 & 545 & 25.7 \\
\hline POLAND & 50 & 37 & 38 & 830 & 10.0 \\
\hline ROMANIA & 30 & 31 & 32 & 537 & 19.9 \\
\hline RUSSIAN FED. & 30 & 25 & 37 & 281 & 13.4 \\
\hline SERBIA & & & 36 & 635 & 28.4 \\
\hline SLOVAK REPUBLIC & 50 & 47 & 30 & 565 & 25.7 \\
\hline SLOVENIA & 50 & 64 & 32 & 1,350 & 18.6 \\
\hline TAJIKISTAN & 30 & 22 & 34 & 295 & 20.5 \\
\hline TURKMENISTAN & 10 & 22 & & & \\
\hline UKRAINE & 30 & 28 & 30 & 354 & 41.5 \\
\hline UZBEKISTAN & 30 & 21 & 42 & 195 & 22.2 \\
\hline
\end{tabular}

Notes: Data in columns 1-5 refer to 2008 and in columns 6-9 to 2003. Column 1-3 based on Heritage Foundation / Wall Street J. "Economic Freedom" indices. Columns 4-5 based on World Bank "Doing Business" database. 
Table 2. Regression models explaining property rights and corruption (world-wide sample of countries)

\begin{tabular}{|c|c|c|c|c|c|c|c|c|c|c|}
\hline & \multicolumn{2}{|c|}{ (1) } & \multicolumn{2}{|c|}{ (2) } & \multicolumn{2}{|c|}{$(3)$} & \multicolumn{2}{|c|}{ (4) } & \multicolumn{2}{|c|}{ (5) } \\
\hline Dependent & \multicolumn{2}{|c|}{$\begin{array}{c}\text { Property } \\
\text { Rights (1998) }\end{array}$} & \multicolumn{2}{|c|}{$\begin{array}{c}\text { Freedom from } \\
\text { Corruption (1998) }\end{array}$} & \multicolumn{2}{|c|}{$\begin{array}{c}\text { Property } \\
\text { Rights (2008) }\end{array}$} & \multicolumn{2}{|c|}{$\begin{array}{c}\text { Property } \\
\text { Rights (2008) }\end{array}$} & \multicolumn{2}{|c|}{$\begin{array}{c}\text { Freedom from } \\
\text { Corruption (2008) }\end{array}$} \\
\hline \multirow[t]{2}{*}{ Estimator } & \multicolumn{6}{|c|}{ Ordered probit } & \multicolumn{4}{|c|}{ Ordinary Least Squares } \\
\hline & & Robust & & Robust & & Robust & & Robust & & Robust \\
\hline Explanatory: & Coef. & Std. Err. & Coef. & Std. Err. & Coef. & Std. Err. & Coef. & Std. Err. & Coef. & Std. Err. \\
\hline ln_gdppc (t-1) & $.90 * * *$ & .10 & $.93 * * *$ & .09 & $.75 * * *$ & .10 & $11.73 * * *$ & 1.12 & $11.38 * * *$ & 1.07 \\
\hline French & $-.96^{* * *}$ & .21 & $-.82 * * *$ & .22 & $-.83 * * *$ & .19 & $-11.63 * * *$ & 2.82 & $-6.37 *$ & 2.65 \\
\hline German & -.47 & .44 & -.50 & .33 & -.65 & .40 & -5.84 & 5.71 & 2.62 & 4.77 \\
\hline Scandinavian & .30 & .62 & 1.62 & .54 & $7.48 * * *$ & .23 & $14.46^{* * *}$ & 3.18 & $27.70 * * *$ & 4.18 \\
\hline Socialist & $-.57^{*}$ & .23 & $-.86^{*}$ & .38 & & & & & & \\
\hline CEECE-EU & -.58 & .43 & -.18 & .32 & -.02 & .41 & -4.83 & 6.29 & $-9.49 *$ & 4.24 \\
\hline CEECE-non EU & $-1.07 * *$ & .34 & -.49 & .33 & $-.72 *$ & .31 & $-12.95 *$ & 4.14 & $-13.67 * * *$ & 2.83 \\
\hline _cons & & & & & & & $-47.83 * * *$ & 9.61 & $-54.01 * * *$ & 8.45 \\
\hline $\begin{array}{l}\mathrm{Chi}^{2} / \mathrm{F} \text { statistics } \\
\text { from t-test of H: } \\
\text { CEECE-EU - } \\
\text { CEECE-non EU }=0 \\
\text { No of observations }\end{array}$ & \multicolumn{2}{|c|}{.99} & \multicolumn{2}{|c|}{.49} & \multicolumn{2}{|c|}{2.52} & \multicolumn{2}{|c|}{1.51} & \multicolumn{2}{|c|}{1.08} \\
\hline
\end{tabular}

Notes:

*** Significant at $.001 ; * *$ Significant at $.01 ; *$ Significant at $.05 ; \uparrow$ Significant at .1

Variable names:

property rights, freedom from corruption: both as defined by the Heritage Foundation / Wall Street Journal

ln_gdppc (t-1): natural logarithm of gross domestic product per capita, purchasing power parity, 2005 constant US dollars, lagged one year with respect to the dependent variable (source: World Bank, WDI)

French, German, Scandinavian socialist: correspondingly indicating a legal origin, with English as a benchmark, omitted category (source: Andrei Schleifer's database accessed at $<$ http://www.economics.harvard.edu/faculty/shleifer/dataset $>$ on the $7^{\text {th }}$ of February 2009.

Socialist legal-origin category relates to two countries: North Korea and Myanmar. It is dropped in specification 3-5 due to data missingness. When those two countries are excluded from estimations in models 1-2 as well, the results are not affected.

CEECE-EU: a dummy variable representing a transition economy of CEECA region which had the EU agreement by 1995 (equivalent to the EU membership in 2008)

CEECE-Non EU: a dummy variable representing a transition economy of CEECA region which did not have the EU agreement by 1995 (equivalent to not being the the EU member in 2008) 
Table 3. Corporate governance and corporate ownership structures in Central Eastern Europe and Central Asia

\begin{tabular}{|c|c|c|c|c|c|}
\hline Country & $\begin{array}{l}{[1] \text { EBRD indicator of }} \\
\text { governance and restructuring }\end{array}$ & $\begin{array}{l}\text { [2] EBRD indicator of large scale } \\
\text { privatisation }\end{array}$ & $\begin{array}{l}\text { [3] EBRD indicator of } \\
\text { bank reform }\end{array}$ & $\begin{array}{l}\text { [4] EBRD indicator of } \\
\text { securities markets }\end{array}$ & $\begin{array}{l}\text { [5] Legal } \\
\text { origin }\end{array}$ \\
\hline ALBANIA & 2.33 & 3.33 & 3.00 & 1.67 & French \\
\hline ARMENIA & 2.33 & 3.67 & 2.67 & 2.00 & French \\
\hline AZERBAIJAN & 2.00 & 2.00 & 2.33 & 1.67 & French \\
\hline BELARUS & 1.67 & 1.67 & 2.00 & 1.00 & German \\
\hline BOSNIA & 2.00 & 3.00 & 3.00 & 1.67 & German \\
\hline BULGARIA & 2.67 & 4.00 & 3.67 & 3.00 & German \\
\hline CROATIA & 3.00 & 3.33 & 4.00 & 3.00 & German \\
\hline CZECH REPUBLIC & 3.33 & 4.00 & 4.00 & 3.67 & German \\
\hline ESTONIA & 3.67 & 4.00 & 4.00 & 3.67 & German \\
\hline FYR MACEDONIA & 2.67 & 3.33 & 3.33 & 2.33 & French \\
\hline GEORGIA & 2.33 & 4.00 & 2.67 & 1.67 & French \\
\hline HUNGARY & 3.67 & 4.00 & 4.00 & 4.00 & German \\
\hline KAZAKHSTAN & 2.00 & 3.00 & 3.00 & 2.67 & French \\
\hline KYRGYZ REP. & 2.00 & 3.67 & 2.33 & 2.00 & French \\
\hline LATVIA & 3.00 & 3.67 & 4.00 & 3.00 & German \\
\hline LITHUANIA & 3.00 & 4.00 & 3.67 & 3.33 & French \\
\hline MOLDOVA & 2.00 & 3.00 & 3.00 & 2.00 & French \\
\hline MONGOLIA & 2.00 & 3.33 & 2.67 & 2.33 & German \\
\hline MONTENEGRO & 2.00 & 3.33 & 3.00 & 1.67 & French \\
\hline POLAND & 3.67 & 3.33 & 3.67 & 3.67 & German \\
\hline ROMANIA & 2.33 & 3.67 & 3.33 & 3.00 & French \\
\hline RUSSIAN FED. & 2.33 & 3.00 & 2.67 & 3.00 & French \\
\hline SERBIA & 2.33 & 2.67 & 3.00 & 2.00 & French \\
\hline SLOVAK REPUBLIC & 3.67 & 4.00 & 3.67 & 3.00 & German \\
\hline SLOVENIA & 3.00 & 3.00 & 3.33 & 3.00 & German \\
\hline TAJIKISTAN & 1.67 & 2.33 & 2.33 & 1.00 & French \\
\hline TURKMENISTAN & 1.00 & 1.00 & 1.00 & 1.00 & French \\
\hline UKRAINE & 2.00 & 3.00 & 3.00 & 2.67 & French \\
\hline UZBEKISTAN & 1.67 & 2.67 & 1.67 & 2.00 & French \\
\hline
\end{tabular}


Table 4. Self-dealing in CEECA.

\begin{tabular}{|c|c|c|c|c|}
\hline Country & [1] Ex-ante control of self dealing & [2] Ex-post control of self dealing & [3] Anti-self-dealing index & [4] Public enforcement index \\
\hline BULGARIA & 0.83 & 0.48 & 0.65 & 0 \\
\hline CROATIA & 0.17 & 0.33 & 0.25 & 0.5 \\
\hline CZECH REPUBLIC & 0.17 & 0.50 & 0.33 & 1 \\
\hline HUNGARY & 0.00 & 0.36 & 0.18 & 0 \\
\hline KAZAKHSTAN & 0.67 & 0.30 & 0.48 & 0 \\
\hline LATVIA & 0.14 & 0.50 & 0.32 & 1 \\
\hline LITHUANIA & 0.14 & 0.58 & 0.36 & 0 \\
\hline POLAND & 0.25 & 0.33 & 0.29 & 1 \\
\hline ROMANIA & 0.33 & 0.55 & 0.44 & 1 \\
\hline RUSSIAN FED. & 0.81 & 0.08 & 0.44 & 1 \\
\hline SLOVAK REP. & 0.06 & 0.53 & 0.29 & 0 \\
\hline UKRAINE & 0.00 & 0.16 & 0.08 & 1 \\
\hline
\end{tabular}

Source: Djankov et al. (2008). 
Table 5. Regression models explaining anti-self-dealing index and stock market characteristics

\begin{tabular}{|l|c|c|c|c|}
\hline & \multicolumn{2}{|c|}{$(1)$} & \multicolumn{2}{c|}{$(2)$} \\
\hline \multicolumn{1}{|c|}{ Dependent } & \multicolumn{2}{|c|}{ anti_selfd } & \multicolumn{2}{c|}{ anti_selfd } \\
\hline & & Robust & & Robust \\
Explanatory: & Coef. & Std. Err. & Coef. & Std. Err. \\
\hline ln_gdppc & $0.04^{*}$ & 0.02 & $0.05^{*}$ & 0.02 \\
French & $-0.34^{* * *}$ & 0.05 & $-0.34^{* * *}$ & 0.06 \\
German & $-0.31^{* * *}$ & 0.07 & $-0.32^{* * *}$ & 0.10 \\
Scandinavian & $-0.37 * * *$ & 0.07 & $-0.37^{* * *}$ & 0.07 \\
\hline CEECA-EU & & & 0.03 & 0.85 \\
CEECA-nonEU & & & 0.02 & 0.10 \\
\hline cons & $0.31^{*}$ & 0.15 & $0.29 \dagger$ & 0.17 \\
\hline
\end{tabular}

Notes:

*** Significant at $.001 ; * *$ Significant at $.01 ; *$ Significant at $.05 ; \uparrow$ Significant at .1

Number of observations: 72

Apart from $C E E C E-E U$ and $C E E C E-n o n E U$ variables (please see definitions provided as notes to Table 3), all data based on Djankov et al (2008) and $<$ http://www.economics.harvard.edu/faculty/shleifer/dataset $>$.

Variables:

anti_selfd: anti-self dealing index, as defined by Djankov et al (2008)

ln_gdppc: natural logarithm of gross domestic product per capita

French, German, Scandinavian: correspondingly indicating a legal origin (with English as a benchmark, omitted category) 
Table 6. Regression models explaining selected EBRD reform indicators

\begin{tabular}{|c|c|c|c|c|c|c|c|c|}
\hline & \multicolumn{2}{|c|}{ (1) } & \multicolumn{2}{|c|}{ (2) } & \multicolumn{2}{|c|}{ (3) } & \multicolumn{2}{|c|}{ (4) } \\
\hline \multirow[t]{2}{*}{ Dependent } & \multicolumn{2}{|c|}{$\begin{array}{c}\text { Governance and } \\
\text { enterprise } \\
\text { restructuring (2008) }\end{array}$} & \multicolumn{2}{|c|}{$\begin{array}{c}\text { Large scale } \\
\text { Privatisation (2008) }\end{array}$} & \multicolumn{2}{|c|}{$\begin{array}{c}\text { Banking reform } \\
(2008)\end{array}$} & \multicolumn{2}{|c|}{$\begin{array}{c}\text { Securities markets } \\
\text { (2008) }\end{array}$} \\
\hline & \multirow[b]{2}{*}{ Coef. } & \multirow{2}{*}{$\begin{array}{l}\text { Robust } \\
\text { Std. Err. }\end{array}$} & \multirow[b]{2}{*}{ Coef. } & \multirow{2}{*}{$\begin{array}{l}\text { Robust } \\
\text { Std. Err. }\end{array}$} & \multirow[b]{2}{*}{ Coef. } & \multirow{2}{*}{$\begin{array}{l}\text { Robust } \\
\text { Std. Err. }\end{array}$} & & Robust \\
\hline Explanatory & & & & & & & Coef. & Std. Err. \\
\hline EU association agreement in 1998 & .09 & .06 & $.23 *$ & .09 & $.14 \dagger$ & .08 & .06 & .06 \\
\hline Constraints on executive (1995) & $.87 * * *$ & .22 & .10 & .30 & $.63 * *$ & .21 & $1.10^{* * *}$ & .22 \\
\hline cons & $1.76^{* * *}$ & 0.25 & $2.08 * * *$ & 0.40 & $2.11 * * *$ & .39 & $1.86^{* * *}$ & .28 \\
\hline
\end{tabular}

Notes:

$* * *$ Significant at $.001 ; * *$ Significant at $.01 ; *$ Significant at $.05 ; \uparrow$ Significant at .1

Number of observations: 28

The independent variables:

EU association agreement: a dummy variable representing the countries with the EU association agreement signed by 1998 . It is the same group of 10 countries that became the EU members in 2004-2007.

Constraints on executive branch of the government: the measure reported by the Polity IV project, see Marshall and Jaggers (2007). The value relates to 1998. Dependent variables:

EBRD indicators for 2008, as reported in Table 3, columns 3-6, above. 
Table 7. Corporate governance and corporate ownership structures in Central Eastern Europe and Central Asia

\begin{tabular}{|c|c|c|}
\hline Country & $\begin{array}{l}\text { [1] average } \% \text { shares held by } \\
\text { the largest shareholder(s) }\end{array}$ & $\begin{array}{l}\text { [2] \% of companies with more than } \\
\text { one blockholder }\end{array}$ \\
\hline ALBANIA & 76.47 & 21.2 \\
\hline ARMENIA & 67.11 & 31.9 \\
\hline AZERBAIJAN & 87.13 & 14.8 \\
\hline BELARUS & 73.18 & 12.6 \\
\hline BOSNIA & 76.19 & 7.7 \\
\hline BULGARIA & 74.42 & 14.7 \\
\hline CROATIA & 69.90 & 15.2 \\
\hline CZECH REPUBLIC & 79.56 & 23.1 \\
\hline ESTONIA & 76.61 & 20.0 \\
\hline FYR MACEDONIA & 75.37 & 6.9 \\
\hline GEORGIA & 65.27 & 24.0 \\
\hline HUNGARY & 77.77 & 24.7 \\
\hline KAZAKHSTAN & 69.72 & 31.6 \\
\hline KYRGYZ REP. & 69.34 & 13.5 \\
\hline LATVIA & 68.71 & 15.1 \\
\hline LITHUANIA & 75.12 & 20.0 \\
\hline MOLDOVA & 64.64 & 33.0 \\
\hline MONGOLIA & N/A & N/A \\
\hline MONTENEGRO & N/A & N/A \\
\hline POLAND & 68.18 & 21.7 \\
\hline ROMANIA & 74.42 & 17.4 \\
\hline RUSSIAN FED. & 64.48 & 37.9 \\
\hline SERBIA & 69.02 & 15.4 \\
\hline SLOVAK REPUBLIC & 79.68 & 20.0 \\
\hline SLOVENIA & 67.47 & 15.6 \\
\hline TAJIKISTAN & 78.35 & 13.2 \\
\hline TURKMENISTAN & N/A & N/A \\
\hline UKRAINE & 76.15 & 10.8 \\
\hline UZBEKISTAN & 53.83 & 9.9 \\
\hline
\end{tabular}

Notes: Source - authors' calculations based on BEEPS survey (2005). 
Figure 1. Regression of property rights (2008) on logarithm of GDP p.c. ppp (2007): residuals for CEECA economies

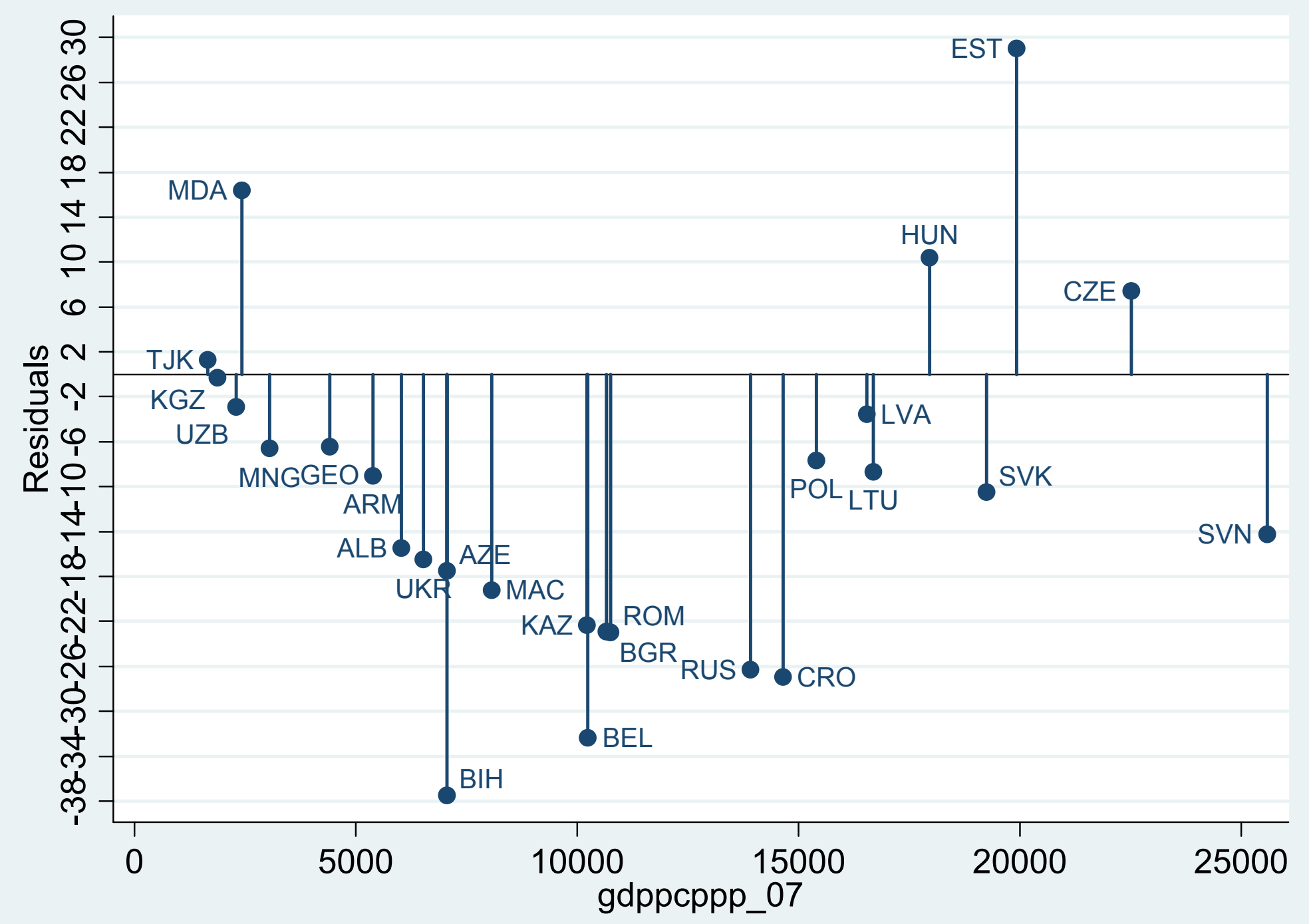

Sources of data: property rights - Heritage Foundation / Wall Street Journal, GDP pc ppp - World Bank WDI, residuals - authors' calculation. 
Figure 2. Regression of freedom from corruption (2008) on logarithm of GDP p.c. ppp (2007); residuals for CEECA economies

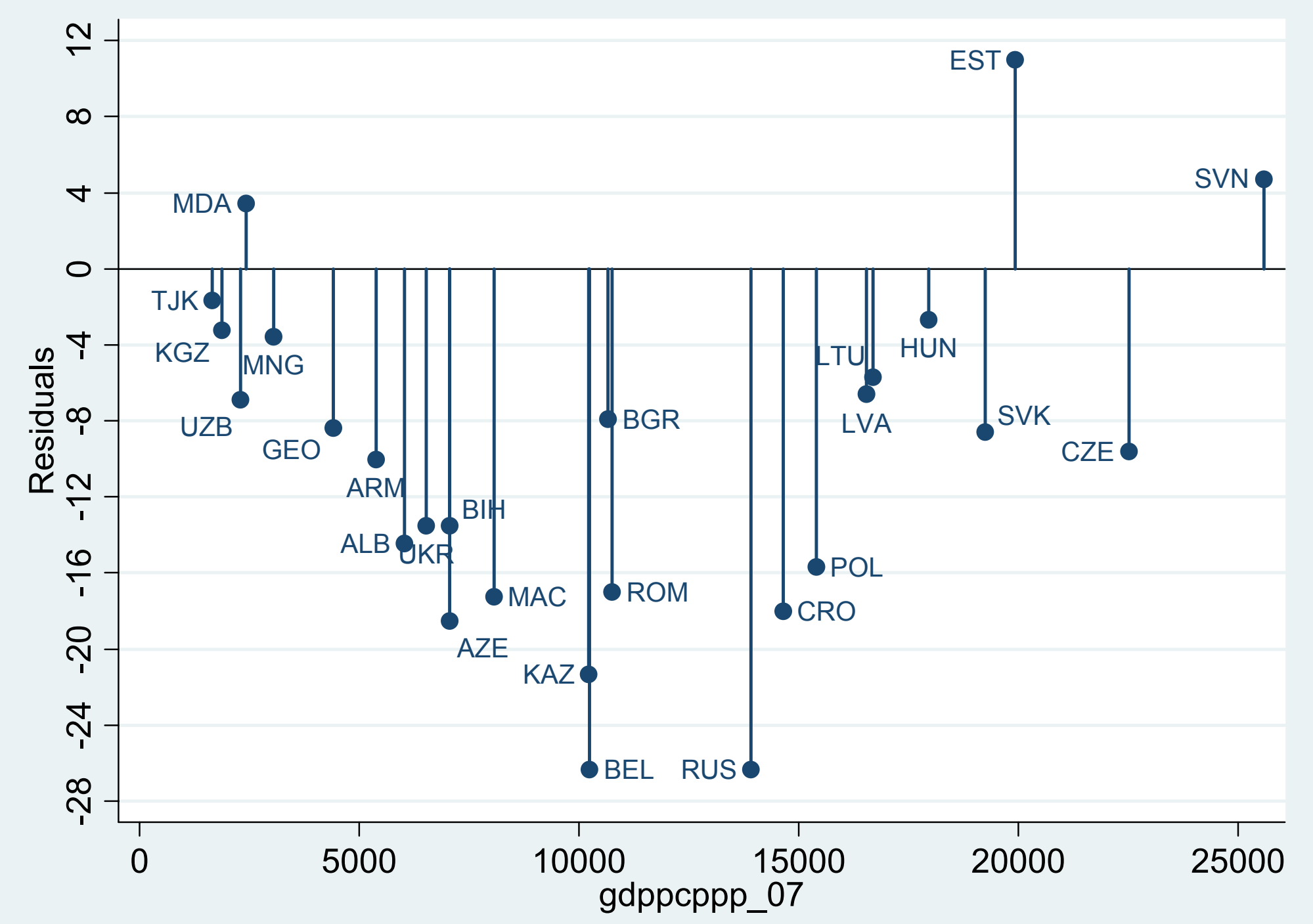

Sources of data: corruption - Heritage Foundation / Wall Street Journal, GDP pc ppp - World Bank WDI, residuals - authors' calculation. 
Figure 3. Corporate Governance Codes: principal components extracted by Heugens and Otten (2007)

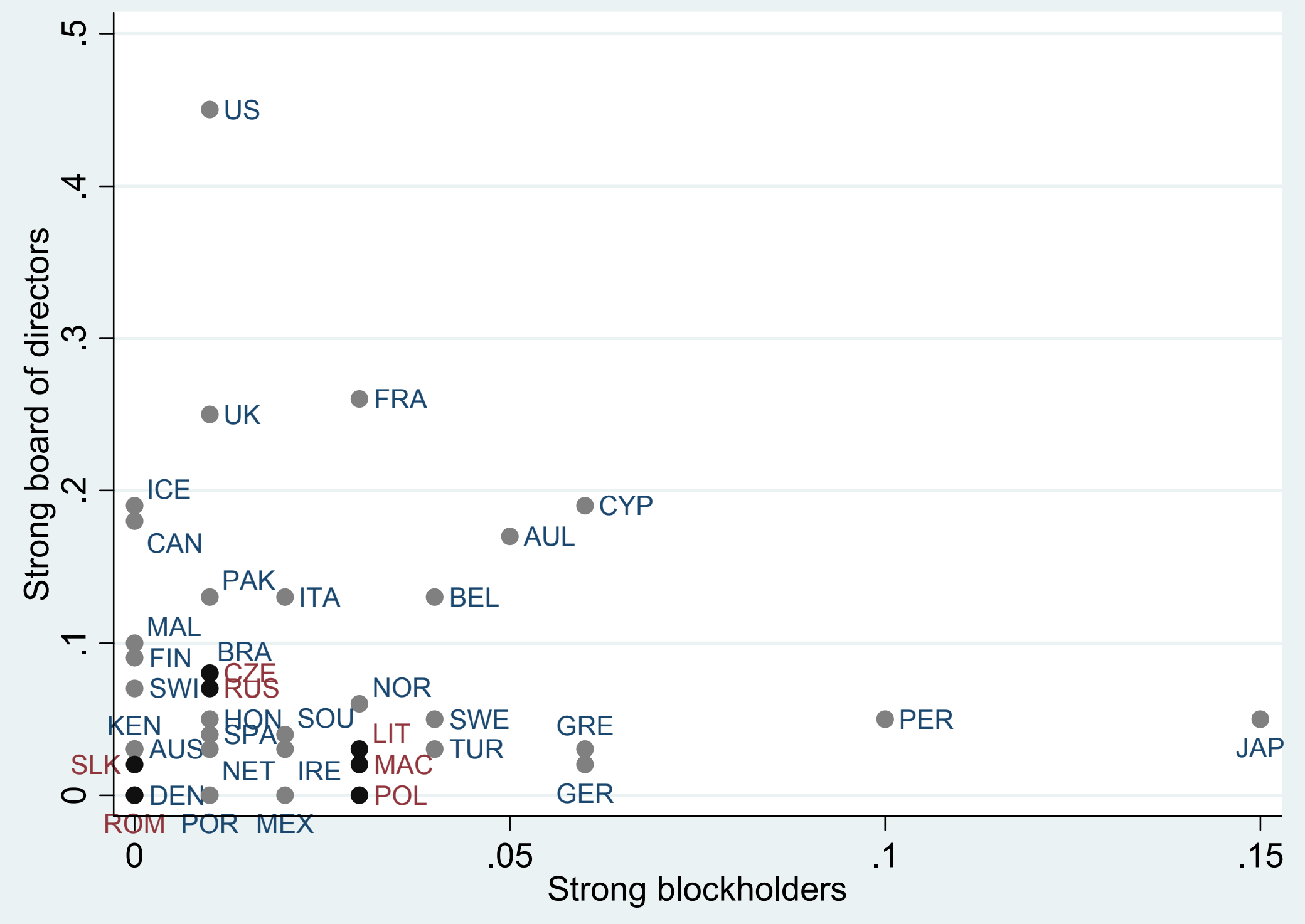


Figure 4. "Equivalent privatisation": private sector share in GDP and privatisation revenues

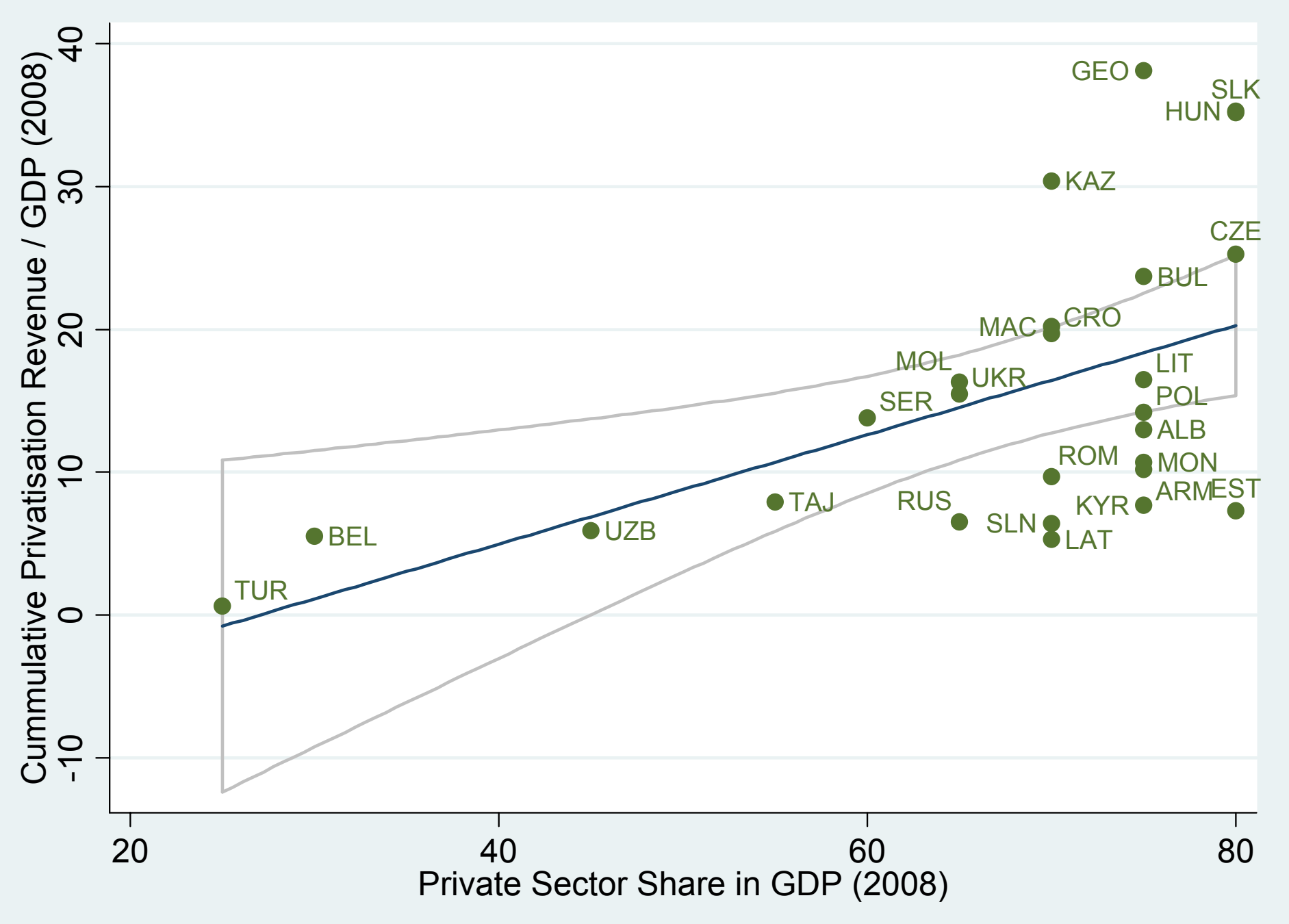

Source of data: EBRD 


\section{CSESCE Working Papers}

89 Macroeconomic stability, Governance and Growth: Empirical Lessons from the Post-Communist Transition by Christopher J Gerry, Jong-Kyu Lee and Tomasz M Mickiewicz

88 Entrepreneurship in Russia. by Ruta Aidis, Julia Korosteleva and Tomasz Mickiewicz

87 Utility Payments in Ukraine: affordability, subsidies and arrears. by Samuel Fankhauser, Yulia Rodionova and Elisabetta Falcetti

86 Voluntary Enrolment in the Peruvian Private Pension System. by Carmen A Li and Javier Olivera

85 Why are Optimistic Entrepreneurs Successful? An Application of the Regulatory Focus Theory by Ruta Aidis, Tomasz Mickiewicz and Arnis Sauka

\section{CSESCE Working Papers}

84 The Sustainability of Russia's Energy Power: Implications for the Russian Economy by Philip Hanson

83 'Oligarchs', Business and Russian Foreign Policy: From El'tsin to Putin by Peter J S Duncan

82 Policies for promoting technological catching up: towards post-Washington approach by Slavo Radosevic

81 Entrepreneurship in Emerging Markets: Which Institutions Matter? by Ruta Aidis, Saul Estrin and Tomasz Mickiewicz

80 Oil and Gas: a Blessing for Few. Hydrocarbons and Within- Region Inequality in Russia by Tullio Buccellato and Tomasz Mickiewicz

79 Institutions and Entrepreneurship Development in Russia: A Comparative Perspective by Ruta Aidis, Saul Estrin and Tomasz Mickiewicz

78 Corporate Governance and Control in Russian Banks by Andrei Vernikov

77 Institutions, Infrastructure, and Trade by Joseph Francois and Miriam Manchin

76 The Great Divide: "Ruralisation" of Poverty in Russia by Christopher J Gerry, Eugene Nivorozhkin and John A Rigg

75 Research and Development and Competitiveness in South Eastern Europe: Asset or Liability for EU Integration? by Slavo Radosevic

74 Inequality, Democracy and Taxation: Lessons from the Post-Communist Transition by Christopher J Gerry and Tomasz M Mickiewicz

73 National Systems of Innovation and Entrepreneurship: In Search of a Missing Link by Slavo Radosevic

72 Convergence across Russian Regions: A Spatial Econometrics Approach by Tullio Buccellato

\section{CSESCE Working Papers}

71 Knowledge Based Entrepreneurship in the Czech Republic and Hungary: Results from 4 case studies by Kate Bishop

70 Do Institutions Matter for Technological Change in Transition Economies? The Case of Russia's 89 regions and republics by Brigitte Granville and Carol Leonard Growth, Integration and Spillovers in the Central and East European Software Industry by Slavo Radošević

68 Nature \& determinants of productivity growth of Foreign subsidiaries in Central \& East European countries by Boris Majcen, Slavo Radošević \& Matija Rojec

67 Russia: Firm Entry and Survival. by Ruta Aidis and Yuko Adachi

66 Between Vision and Reality: Promoting Innovation through Technoparks in Kazahkstan. by Slavo Radosevic and Marat Myrzakhmet 
65 Fiscal Policy and Policy Rules in Poland. by Rafal Benecki, Jens Hölscher and Mariusz Jarmuzek

64 Construction of Home by Polish and Lithuanian Migrants in the UK by Violetta Parutis

63 Ownership Structure and Development of Polish Life Insurance Companies: Evidence from 1991 to 2004 by Adam Sliwinski

62 Corporate Governance, Managers' Independence, Exporting and Performance of Firms in Transition Economies by Igor Filatotchev, Natalia Isachenkova and Tomasz Mickiewicz

\section{CSESCE Working Papers}

61 Entrepreneurship in Transition Economies: A Review by Ruta Aidis

60 New Estimates of the Risk and Duration of Registered Unemployment in Urban Russia by Anton Nivorozhkin

59 De-industrialisation and the Post-Communist Transition: Rowthorn and Well's Model Revisited by Tomasz Mickiewicz and Anna Zalewska

58 Upgrading Russian Enterprises from the Value Chain Perspective: the Case Study of Tube \& Pipe, and Furniture Sectors

Svetlana Avdasheva, Igor Budanov, Victoria Golikova and Andrei Yakovlev

57 The Promotion of Innovation in Slovenia through Knowledge Transfer from Higher Education Institutions to SME's

Will Bartlett and Vladimir Bukvič

56 Reconstitution of Post-Soviet Ex-State Enterprises into Russian Business Firms under Institutional Weaknesses

Yuko Adachi

$55 \quad$ Post-Communist Recessions Re-examined

Tomasz M. Mickiewicz

$54 \quad$ Leadership and Corruption in Russia, 2000-2004

Alena V. Ledeneva

53 Foreign Direct Investment and Restructuring in the Automotive Industry in Central and East Europe

Slavo Radosevic and Andrew Rozeik

52 Financial Performance of Groups of Companies in Poland against the Background of Historical Determinants and Knowledge Management Procedures Applied

Jan Chadam and Zbigniew Pastuszak

$51 \quad$ Are the EU New Member States Fiscally Sustainable? An Empirical Analysis Mariusz Jarmuzek

50 Growth Expectations of Business Owners: Impact of Human Capital, Firm Characteristics and Environmental Transition

Ruta Aidis and Tomasz Mickiewicz

49 Firms' capabilities related to the economic system: cases from Ukraine and Russia

Gustavo Rinaldi

\section{CSESCE Working Papers}

48 Ambiguity of Social Networks in Post-Communist Contexts

Alena V. Ledeneva

47 Privatisation, Corporate Control and Employment Growth: Evidence from a Panel of Large Polish Firms, 1996-2002'

Tomasz Mickiewicz, Christopher J Gerry and Kate Bishop 